\title{
Hubungan Peran Teman, Peran Orang Tua,Besaran Uang Saku dan Persepsi Terhadap Jajanan Dengan Kejadian Gizi Lebih Pada Anak Sekolah (Studi di SD Negeri Ploso 1/172 Kecamatan Tambaksari Surabaya Tahun 2017)
}

\section{Relationship between the role of friends, the role of parents, pocket money and perception of snack with overweight incidence}

\author{
Herlina Arisdanni*, Annas Buanasita ${ }^{1}$
}

\begin{abstract}
ABSTRAK
Latar Belakang : Gizi lebih (obesitas dan overweight) menjadi permasalahan yang tidak hanya terjadi pada saat dewasa tetapi mulai dari anak-anak, tak terkecuali anak sekolah. Faktor penyebab langsung gizi lebih adalah pola makan, sedangkan faktor yang dapat mempengaruhi pola makan antara lain peran teman, peran orang tua, besaran uang saku dan persepsi terhadap jajanan.

Tujuan : Penelitian ini bertujuan untuk menganalisis hubungan peran teman, peran orang tua, besaran uang saku dan persepsi terhadap jajanan dengan kejadian gizi lebih pada anak sekolah.

Metode : Penelitian ini menggunakan desain studi case control yang melibatkan 110 anak sekolah, dengan sampel kasus sebanyak 55 dan sampel kontrol sebanyak 55 dengan analisis data menggunakan uji chi square dan uji regresi linear.

Hasil : Hasil uji regresi linear menunjukkan bahwa ada hubungan yang signifikan antara peran orang tua $(p=0.006)$, peran teman $(p=0.000)$, persepsi terhadap jajanan $(p=0.045)$, dan besaran uang saku $(p=0.023)$ dengan kejadian gizi lebih pada anak sekolah.

Kesimpulan: Peran teman dan persepsi terhadap jajanan menunjukkan hubungan positif yang dapat beresiko terhadap kejadian gizi lebih,sedangkan peran orang tua dapat menjadi faktor yang protektif terhadap gizi lebih. Saran penelitian, perlu pendidikan gizi untuk anak sekolah agar memiliki persepsi yang benar terhadap jajanan dan orang tua perlu memperhatikan pemilihan jajanan sehat untuk mencegah kejadian gizi lebih pada anak sekolah.
\end{abstract}

Kata Kunci: uang saku,peran teman, jajanan 


\section{ABSTRACT}

Background :Overweight and obesity becomes a problem that not only occurs in adulthood but also started from childhood. The direct cause overweight is food consumption pattern, while the factors that can affect of it such as :the role of friends, the role of parents, pocket money and perceptions of snacks.

Objectives :This study aimed to analyze the relationship between the role of friends, the role of parents, pocket money and perceptions of snacks with overweight incidents in school children.

Methods : This research with a case control design study involved 110 respondents with 55 case samples, and 55 control samples. Data were analyzed using chi square test and linear regression.

Results: The results showed that was a significant correlation between the role of parents $(p=0.006))$, the role of friends $(p=0.000)$, perceptions of snack $(p=0.045)$, pocket money $(p=0.023)$ with overweight incidence.

Conclusion : The role of friends and perceptions of snacks show positive correlation that could be at risk for overweight incidents, meanwhile the role of parents show a protective factors for overweight incidents. It is suggested to give nutrition education to school children, so that they have the correct perception about snacks and the parents to pay attention about healthy snacks to prevent overweight incidents in school children.

Keywords: pocket money, the role of friends, snacks

*Koresponden:

herlinna.elin@gmail.com

${ }^{1}$ Akademi Gizi Surabaya

\section{PENDAHULUAN}

Obesitas merupakan masalah kesehatan di negara maju dan berkembang seperti Indonesia. Obesitas tidak hanya terjadi pada orang dewasa bahkan terjadi pada anak-anak umur 6-12 tahun (usia sekolah). Prevalensi obesitas di Indonesia terlihat meningkat, berdasarkan Riset Kesehatan Dasar pada tahun 2010 menunjukkan prevalensi sebesar 9.2\% dan menjadi $18.8 \%$ pada tahun 2013. Provinsi Jawa Timur menunjukan presentase yang melebihi prevalensi nasional yaitu sebesar $19.2 \%$ pada tahun $2013 .{ }^{1}$ Obesitas pada anak sekolah dapat disebabkan karena gaya hidup yang cenderung mengkonsumsi makanan tinggi lemak dan kolesterol yang dapat meningkatkan kalori pada tubuh. Pola konsumsi makanan, termasuk pola konsumsi jajanan dapat mempengaruhi status gizi pada anak sekolah.

Faktor yang berpengaruh secara langsung terhadap status gizi lebih adalah pola konsumsi makan. Pola konsumsi makan anak dapat dipengaruhi oleh sistem sosial disekitarnya seperti peran teman dan peran ortu. Hampir sebagian besar waktu anak, dihabiskan di sekolah sehingga pengaruh teman menjadi lebih besar. ${ }^{2}$ Salah satu peran negatif teman sebaya adalah dalam memilih makanan yang tidak sehat. ${ }^{3}$ Peran teman menjadi sangat bermakna ketika anak sekolah dituntut untuk dapat menyesuaikan diri didalam kelompoknya, sehingga mereka terkadang hanya mengkonsumsi makanan karena ingin diterima di kalangan teman, tanpa menghiraukan kandungan gizinya. ${ }^{4}$ Peran orang tua sangat dibutuhkan untuk membentuk kebiasaan/pola konsumsi makan yang baik bagi anak, dikarenakan orang tua memiliki peran yang sangat dekat dan dapat membentuk kebiasaan makan anak sejak kecil. ${ }^{5}$ Selain itu, orang tua berperan sebagai fasilitator pemberi asupan yang baik bagi anak, mengontrol serta menuntun anak pada kebiasaaan makan yang baik. ${ }^{6}$ 
Faktor lain yang berhubungan dengan kejadian gizi lebih adalah uang saku. ${ }^{7}$ Besaran terhadap makanan termasuk makanan jajanan, sehingga besaran uang saku juga dapat meningkatkan kesempatan untuk mengkonsumsi jajanan lebih banyak. ${ }^{8} \mathrm{Hal}$ ini dikarenakan akan timbul sikap dan persepsi anak untuk bebas dalam memilih jajanan yang mereka sukai. ${ }^{9}$ Jajanan yang disukai anak cenderung dikonsumsi secara berlebihan, sehingga dapat meningkatkan resiko terhadap kejadian obesitas/overweight. ${ }^{10}$

Selain dipengaruhi oleh faktor sistem sosial, pola konsumsi makanan juga dipengaruhi oleh faktor individual seperti persepsi. ${ }^{11}$ Persepsi merupakan orientasi atau penilaian seseorang terhadap objek. $^{12}$ Persepsi terhadap jajanan merupakan penilaian terhadap karakteristik jajanan yang

dapat menimbulkan ketertarikan seseorang untuk mengkonsumsinya. Persepsi merupakan faktor yang berhubungan dengan pengetahuan anak selain dipengaruhi oleh motivasi atau dukungan dari sistem sosial di lingkungan anak. ${ }^{13}$ Ketertarikan anak terhadap karakteristik jajanan dapat menjadi faktor kuat anak sekolah untuk mengkonsumsi makanan tersebut, apalagi makanan yang disukai anak sekolah cenderung dikonsumsi secara berlebihan. ${ }^{14}$

Penelitian ini bertujuan untuk mengetahui hubungan antara peran teman, peran ortu, besaran uang saku dan persepsi terhadap jajanan dengan status gizi lebih pada anak sekolah.

\section{METODE}

Penelitian ini merupakan jenis penelitian observational analitik. Desain studi penelitian adalah case control, dimana kelompok kasus adalah anak sekolah dengan kategori gizi lebih berdasarkan indeks IMT/U menggunakan standart WHO, 2007 dengan kategori obesitas (Z-Scores $>+2$ ) dan overweight $(+1 \leq \mathrm{Z}$-Scores $<+2)$. Sedangkan kelompok kontrol adalah anak sekolah dengan kategori gizi normal $\left(-2 \leq\right.$ Z-Scores <+1). ${ }^{11}$ Setelah menentukan kelompok kasus, kemudian mengidentifikasi faktor uang saku yang diberikan orang tua untuk jajan dapat meningkatkan daya beli anak resiko/penyebab untuk selanjutnya dianalisis dengan membandingkan proporsi antara faktor resiko dengan kelompok kontrol.

Populasi penelitian meliputi seluruh siswa kelas IV,V dan VI SDN Ploso 1/172 Surabaya tahun ajaran 2016/2017. Cara penentuan sampel yaitu dengan membagi populasi menjadi dua kelompok yaitu kelompok kasus (siswa dengan gizi lebih) dan kelompok kontrol (siswa dengan gizi normal). Teknik pengambilan data menggunakan simple random sampling. Sampel terdiri dari 55 kelompok kasus dan 55 kelompok kontrol, dengan jumlah sampel keseluruhan adalah 110 sampel.

Lokasi penelitian di SDN Ploso 1/172 Surabaya dan pengambilan data dilakukan pada bulan November-Desember 2017. Variabel dependen dalam penelitian ini adalah status gizi sedangkan variabel independen dalam penelitian ini adalah karakteristik anak (umur, jenis kelamin), peran teman, peran orang tua, besaran uang saku, dan persepsi terhadap jajanan.

Peran teman, peran orang tua dan persepsi terhadap jajanan diukur menggunakan kuesioner dengan menggunakan skala likert. Peran teman (7 item pertanyaan), peran orang tua (6 item pertanyaan) dan persepsi terhadap jajanan ( 5 item pertanyaan). Sedangkan uang saku diukur dengan kuesioner menggunakan skala interval besaran uang saku $<R p .3 .500, R p$ 3.500-Rp6.000, dan >Rp 6.000.

Uji etik dilakukan di Ruang Etik Fakultas Kesehatan Masyarakat Universitas Airlangga, tanggal 23 November 2017 dengan No.605KEPK. Analisis data menggunakan uji chi square dan uji regresi linear. Analisis dekskriptif distribusi frekuensi serta hubungan variabel yang berskala data nominal-ordinal menggunakan uji chi square. Sementara, analisis untuk mengetahui hubungan variabel independen dan dependen yang berskala data rasio menggunakan uji regresi linear, dengan nilai $p<0.05$ maka terdapat hubungan antara kedua variabel. 


\section{HASIL DAN PEMBAHASAN}

Berdasarkan hasil penelitian pada Tabel 1 menunjukkan bahwa siswa dengan status gizi lebih sebagian besar berumur 10 tahun. Pada usia sekolah (6-12 tahun) anak mengalami masa pertumbuhan dan perkembangan yang pesat, sehingga berbagai masalah gizi dapat terjadi, salah satunya yaitu obesitas. ${ }^{15}$ Sedangkan berdasarkan karakteristik menurut jenis kelamin, siswa dengan status gizi lebih sebagian besar berjenis kelamin perempuan. $\mathrm{Hal}$ ini dikarenakan perbedaan hormonal yang melekat. $^{16}$

Berdasarkan gambar 1 dapat diketahui bahwa sebagian besar responden gizi lebih memiliki besaran uang saku >Rp 6.000. Anak dengan gizi lebih cenderung memiliki uang saku lebih banyak dibandingkan kelompok gizi normal. Hasil uji statistik dengan menggunakan uji chi square didapatkan nilai $p$-value $=0.023$ yang berarti ada hubungan yang signifikan antara besaran uang saku dengan gizi lebih. Besaran uang saku memiliki hubungan terhadap kejadian gizi lebih pada anak sekolah. Semakin besar uang saku memberikan daya beli yang semakin besar pula, dimana pengeluaran konsumsi makanan dipengaruhi oleh semakin tingginya uang saku seseorang. ${ }^{17}$ Semakin tinggi atau semakin banyak uang saku seseorang beresiko $3.5 \mathrm{x}$ lebih besar untuk menjadi obesitas. ${ }^{18}$

Tabel 1. Karakteristik Anak Berdasarkan Umur, Jenis Kelamin dan Besaran Uang Saku

\begin{tabular}{|c|c|c|c|c|c|}
\hline \multirow{2}{*}{ Karakteristik } & \multicolumn{2}{|c|}{ Gizi Lebih } & \multicolumn{2}{|c|}{ Gizi Normal } & \multirow{2}{*}{$p$-value } \\
\hline & $n$ & $\%$ & $n$ & $\%$ & \\
\hline \multicolumn{6}{|l|}{ Umur } \\
\hline 9 & 9 & 8.2 & 9 & 8.2 & \multirow{4}{*}{$p=0.533$} \\
\hline 10 & 24 & 21.8 & 17 & 15.5 & \\
\hline 11 & 15 & 13.6 & 19 & 17.3 & \\
\hline 12 & 7 & 6.4 & 10 & 9.1 & \\
\hline \multicolumn{6}{|l|}{ Jenis Kelamin } \\
\hline L & 21 & 19.1 & 26 & 23.6 & \multirow[t]{2}{*}{$p=0.441$} \\
\hline$P$ & 34 & 30.9 & 29 & 26.4 & \\
\hline \multicolumn{6}{|l|}{ Uang Saku } \\
\hline$<3.500$ & 9 & 8.2 & 17 & 15.5 & \multirow{3}{*}{$p=0.023$} \\
\hline $3.500-6.000$ & 21 & 19.1 & 26 & 23.6 & \\
\hline$>6.000$ & 25 & 22.7 & 12 & 10.9 & \\
\hline
\end{tabular}

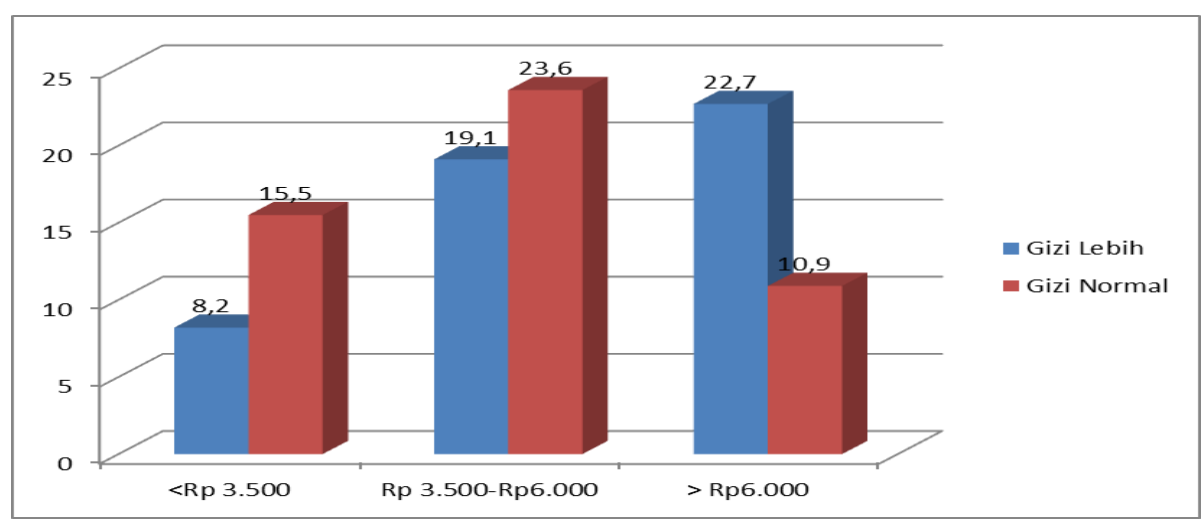

Gambar 1. Persentase Besaran Uang Saku 


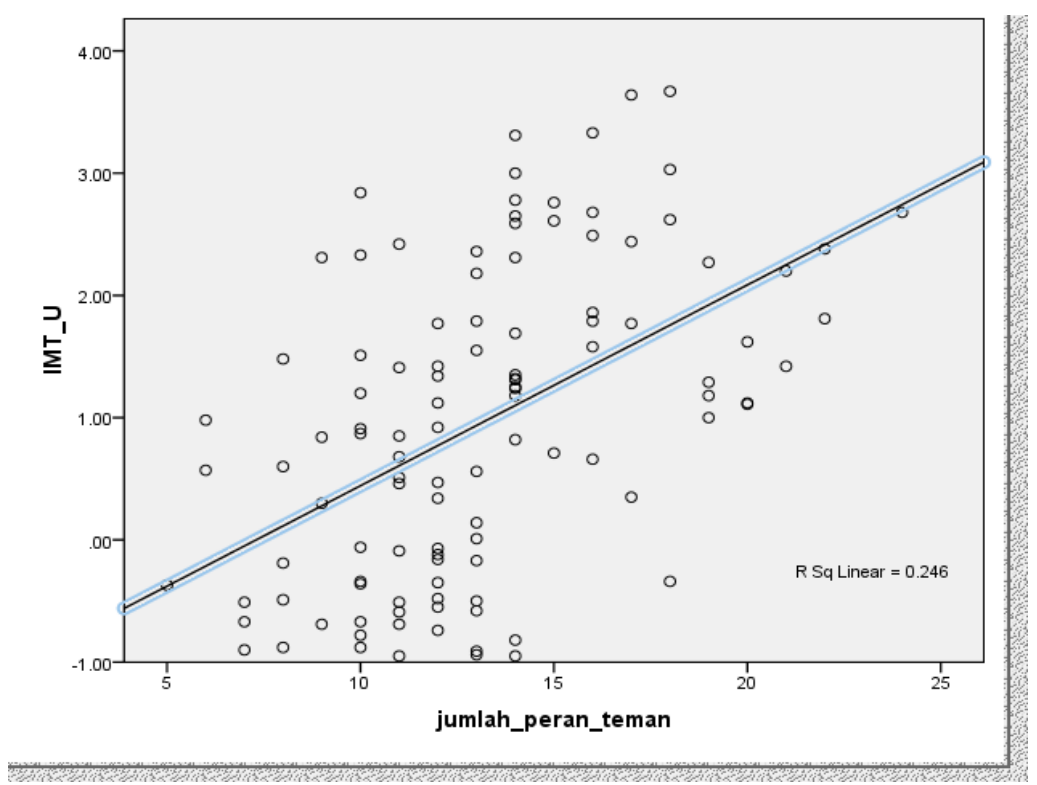

Gambar 2. Hubungan peran teman dengan IMT/U

Nilai rata-rata (mean) peran teman adalah 13.15 yaitu kategori peran teman cukup dan hasil analisis menggunakan uji regresi linear diperoleh nilai $p=0.000$ berarti bahwa ada hubungan peran teman dengan kejadian gizi lebih (obesitas dan overweight). Peran teman dalam hal ini merupakan dukungan teman dalam hal kebiasaan mengkonsumsi jajanan. Semakin tinggi peran teman menunjukkan ada pengaruh teman sebaya untuk memberikan dampak yang dapat membentuk kebiasaan terkait frekuensi ataupun jenis jajanan yang dipilih oleh anak sekolah. Pengaruh teman dalam hal ini menunjukkan pengaruh/kebiasaan yang tidak baik.

Berdasarkan gambar 2 dapat diketahui bahwa ada hubungan yang positif antara peran teman dengan kenaikan IMT/U. Semakin tinggi peran teman, maka akan semakin tinggi pula IMT/U. Hal ini menunjukkan bahwa peran teman berhubungan dengan pola makan anak yang dapat meningkatkan status gizinya. Saat diluar rumah, anak sekolah sering mengkonsumsi makanan bersama dengan temannya, dimana salah satu pengaruh kuat teman adalah dalam memilih makanan yang tidak sehat. ${ }^{19}$

Nilai rata-rata (mean) peran orang tua adalah 20.44 yaitu kategori peran orang tua cukup dan hasil analisis menggunakan uji regresi linear diperoleh nilai $p=0.006$ yang berarti bahwa ada hubungan peran orang tua dengan kejadian gizi lebih (obesitas dan overweight). Peran orang tua dalam hal ini merupakan dukungan/larangan orang tua dalam hal kebiasaan mengkonsumsi jajanan. Semakin tinggi peran orang tua menunjukkan bahwa orang tua memberikan dampak yang baik dalam membentuk kebiasaan terkait frekuensi ataupun jenis makanan jajanan yang dipilih oleh anak sekolah.

Berdasarkan gambar 3 dapat diketahui bahwa ada hubungan yang negatif antara peran orang tua dengan IMT/U. Semakin rendah peran orang tua, maka IMT/U cenderung semakin tinggi (mendekati gizi lebih). Peran orang tua sangat berpengaruh terhadap kebiasaan pola makan anak dan asupan zat gizi pada anak. Peran orang tua berhubungan dengan status gizi anak, dimana semakin tinggi peran orang tua maka status gizi anak semakin baik (gizi normal), namun sebaliknya jika peran orang tua rendah maka anak cenderung mengalami gizi lebih (obesitas dan overweight). ${ }^{20}$ Dalam hal ini orang tua dapat menjadi panutan tentang kebiasaan makan yang baik sehingga berdampak pada pola makan anak. 


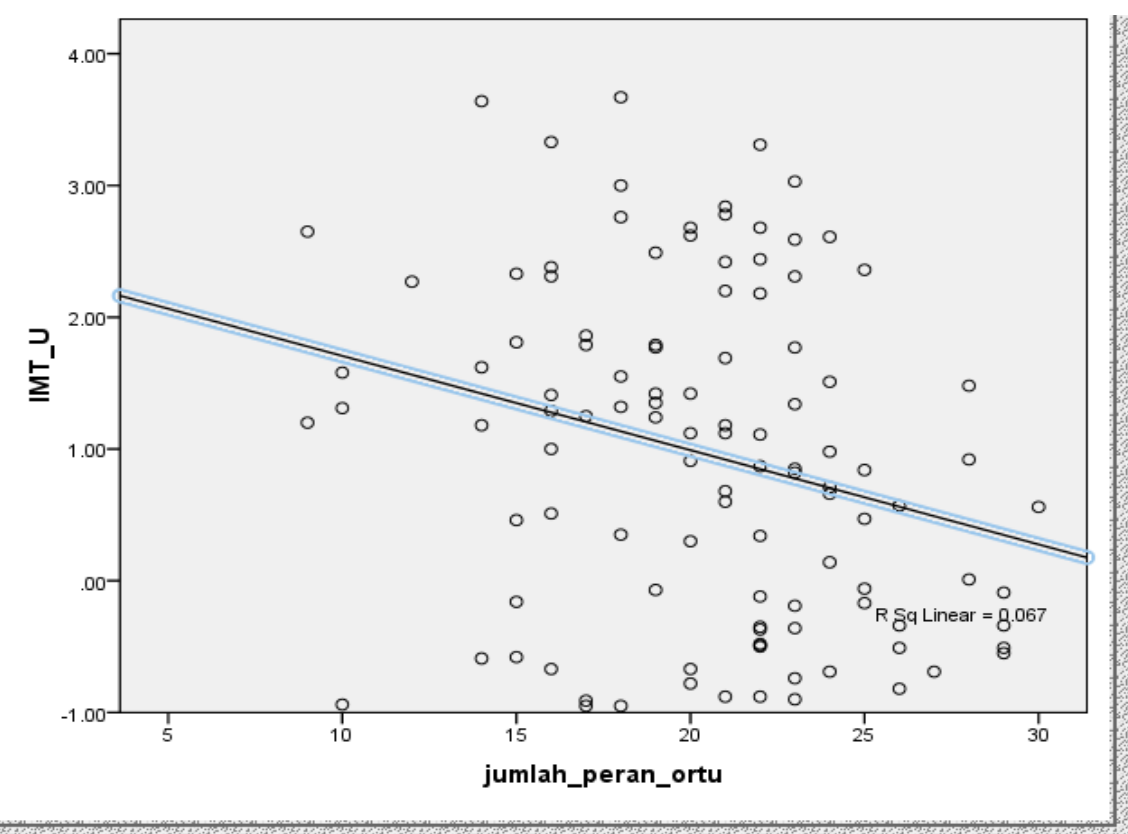

Gambar 3. Hubungan peran orang tua dengan IMT/U

Tabel 2. Faktor-faktor yang berhubungan dengan Kejadian Obesitas/Overweight Menggunakan Uji Regresi Linear

\begin{tabular}{llll}
\hline Faktor Yang Berhubungan & Mean & SD & $\boldsymbol{p}$-value \\
\hline Peran Teman & 13.15 & 3.807 & 0.000 \\
Peran Orangtua & 20.44 & 4.567 & 0.006 \\
Persepsi terhadap jajanan & 12.49 & 4.304 & 0.045 \\
\hline
\end{tabular}

Orang tua dapat memberikan nasehat serta melakukan pengawasan terkait jajanan pilihan anak sekolah.

Orang tua yang dapat memberikan contoh kebiasaan makan yang baik dapat membentuk gaya hidup yang baik pula pada anak yang dapat mempengaruhi status gizinya. Nilai rata-rata (mean) persepsi terhadap jajanan pada tabel 2 adalah 12.49 dengan kategori persepsi rendah dan hasil analisis menggunakan uji regresi linear diperoleh nilai $p=0.045$ yang berarti bahwa ada hubungan antara persepsi terhadap jajanan dengan kejadian gizi lebih (obesitas dan overweight). Persepsi terhadap jajanan dalam penelitian ini merupakan penilaian terhadap karakteristik jajanan meliputi warna, bentuk, rasa dan tampilan yang dapat menimbulkan ketertarikan anak untuk mengkonsumsinya. Semakin tinggi persepsi menunjukkan semakin tinggi daya tarik untuk mengkonsumsi jajanan tersebut. Persepsi yang tinggi merupakan persepsi yang tidak baik, karena menunjukkan ketertarikan akan karakteristik jajanan tanpa menghiraukan kandungan gizinya.

Berdasarkan gambar 4 dapat diketahui bahwa ada hubungan yang positif antara persepsi tentang jajanan dengan IMT/U. Semakin tinggi persepsi tentang jajanan maka semakin tinggi pula IMT/U (mendekati gizi lebih ).

Persepsi anak terhadap karakteristik jajanan meliputi aroma, warna yang beragam dan menarik, serta rasa yang gurih memberikan daya tarik tersendiri sehingga menggugah selera anak sekolah untuk mengkonsumsinya. ${ }^{21}$ Perilaku konsumsi jajanan pada anak salah satunya dipengaruhi oleh persepsi terhadap makanan tersebut, apalagi anak sekolah cenderung mengkonsumsi makanan yang mereka sukai secara berlebihan. ${ }^{22}$ 


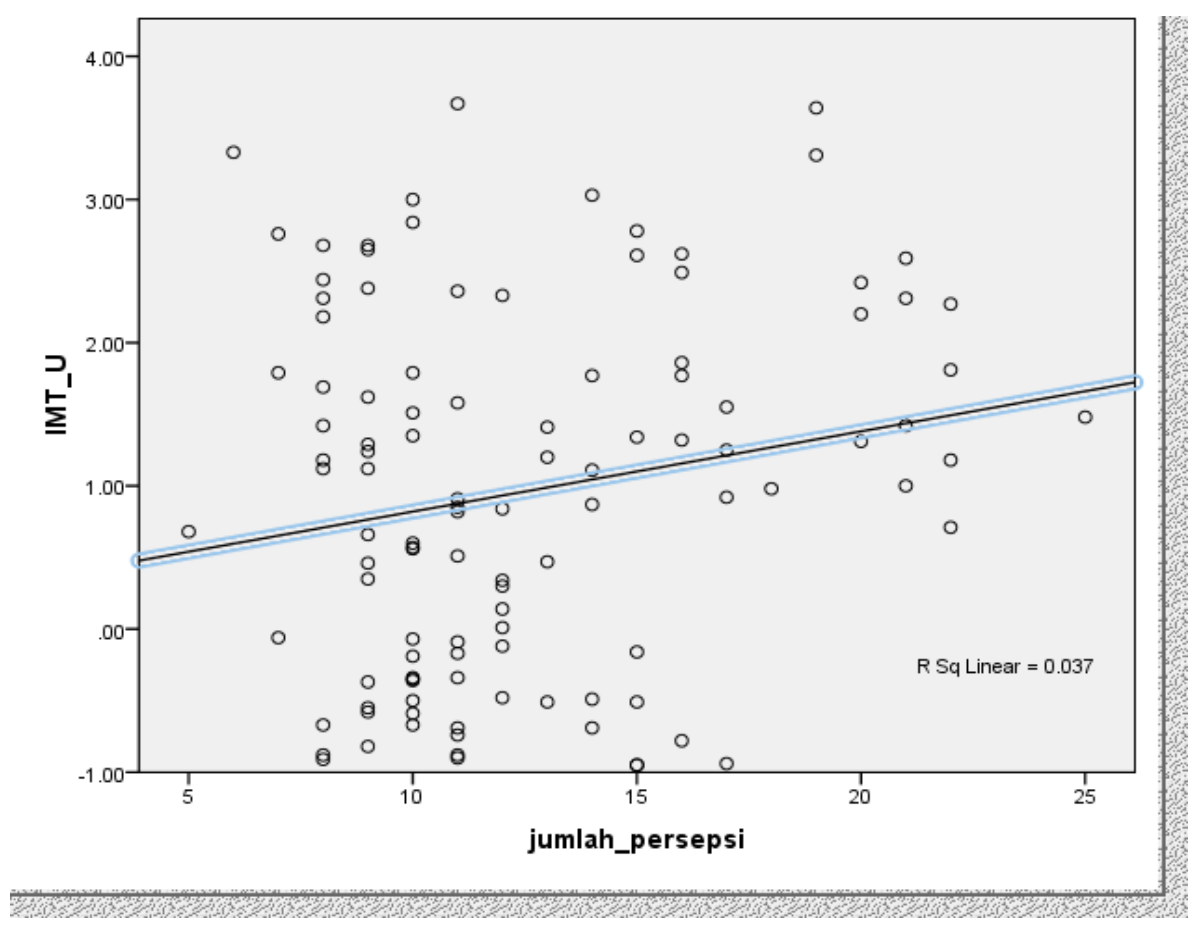

Gambar 4. Hubungan persepsi terhadap jajanan dengan IMT/U

Kelemahan penelitian ini adalah tidak meneliti faktor-faktor yang berhubungan secara langsung dengan status gizi. Sedangkan kelebihan penelitian ini adalah membahas tentang faktor yang secara tidak langsung diduga memiliki hubungan atau dapat menjadi faktor resiko kejadian gizi lebih pada anak sekolah.

\section{KESIMPULAN}

Kesimpulan dari penelitian ini adalah peran teman dan persepsi terhadap jajanan menunjukkan hubungan positif yang dapat beresiko terhadap kejadian gizi lebih, sedangkan peran orang tua dapat menjadi faktor yang protektif terhadap gizi lebih.

Anak sekolah perlu diberikan pendidikan gizi agar memiliki persepsi yang baik terhadap jajanan, sedangkan orang tua diharapkan dapat memperhatikan pemilihan jajanan sehat untuk mencegah kejadian gizi lebih pada anak sekolah.

\section{ACKNOWLEDGMENT}

Terimakasih kepada Dinas Pendidikan Kota Surabaya dan Kepala Sekolah SDN Ploso 1/172, Kecamatan Tambaksari, Surabaya yang telah mengijinkan saya melakukan penelitian di sekolah tersebut.

\section{REFERENSI}

1. Badan Penelitian dan Pengembangan Kesehatan. Riset Kesehatan Dasar (RISKESDAS) 2013. Lap. Nas. 2013 1384 (2013). doi:1 Desember 2013

2. Arlinda, S. Hubungan Konsumsi Fast Food dengan Obesitas Pada Remaja di SMP Muhammadiyah 10 Yogyakarta. (Universitas Aisyiyah Yogyakarta, 2015).

3. Muscari, M. E. Advanced Pediatric Clinical Assessment: Skills and Procedures. (Lippincott Williams \& Wilkins, 2000).

4. Khomsan, A. Pangan dan Gizi untuk Kesehatan. (PT.Raja Grafindo Persada, 2010). 
5. Saifah, A. Hubungan Peran Keluarga, Guru, Teman Sebaya dan Media Massa dengan Perilaku Gizi Anak Usia Sekolah Dasar di Wilayah Kerja Puskesmas Mabelopura Kota Palu. (Universitas Indonesia, 2011).

6. Khasanah, R. . Hubungan Peran Orang Tua Sebagai Fasilitator Pemberian Asupan Makanan dengan Status Gizi Pada Anak Pra Sekolah TK/RA Guppi 1 Kalijambe Sragen. 1-11 (2013).

7. Rosyidah, Z., Andrias, D. . Jumlah Uang Saku dan Kebiasaan Melewatkan Sarapan Berhubungan dengan Status Gizi Lebih Anak Sekolah Dasar. Media Gizi Indones. 10, 1-6 (2016).

8. Moore, M. C. Pocket Guide to Nutritional Assessment and Care. (Elsevier Mosby, 2004).

9. Worthington, B. . Nutrition Throughtout The Lyfe Cycle. (Mcgrawhill Book Companies Inc, 2000).

10. Aprilia, B. . Faktor yang Berhubungan dengan Pemilihan Makanan Jajanan pada Anak Sekolah Dasar. (Universitas Diponegoro, 2011).

11. Notoatmodjo, S. Kesehatan Masyarakat Ilmu dan Seni. (PT Rineka Cipta, 2007).

12. Richards, R., Smith, C. Environmental, parental, and personal influences on food choice, access, and overweight status among homeless children. Soc. Sci. Med. 65, 1572-1583 (2007).

13. Almatsier, S. Daur Kehidupan dan Gizi. (PT.Gramedia Utama, 2011).

14. Ika, S. Faktor-Faktor yang Berhubungan dengan Pemilihan Makanan Cepat Saji pada Mahasiswa Fakultas Kedokteran dan IImu Kesehatan UIN Jakarta Tahun 2012. (UIN Syarif Hidayatullah Jakarta, 2013).

15. Brown, J. . Nutrition Through the Life Cycle, 2nd Edition. (Cengage Learning, 2007).

16. Bhalwar, R. V \& Vaidya, R. Text Book of Public Health and Community Medicine. (Department of Community Medicine, Armed Forces Medical College, 2009).

17. Munawwarah. Gambaran Uang Saku dan Pengeluaran Konsumsi Pangan Pada Penderita Overweight dan Obesitas Mahasiswa Universitas Hasanuddin Angkatan 2013. (Universitas Hasanuddin, 2014).

18. Tina, L., Abdullah, A.Z., Sirajuddin, S. Faktor Risiko Kejadian Obesitas Pada Siswa Sekolah Menengah Atas (SMA) Negeri Di Kota Kendari Tahun 2012. Masy. Epidemiol. Indones. 1, (2012).

19. Kristianto, Y., Riyadi, B. D. \& Mustafa, A. Faktor Determinan Pemilihan Makanan Jajanan pada Siswa Sekolah Dasar. Kesmas J. Kesehat. Masy. Nas. 7, 489494 (2013).

20. Sulistyoningsih, H. Gizi untuk kesehatan ibu dan anak. (Graha ilmu, 2011).

21. Janet, B., Saskia, O., Donna, H. \& Eva, C., Katrine, B., Jan-Willem, K. Nutrients for Cognitive Development in School-aged Children. Nutr. Rev. 62, 295-306 (2004).

22. Wati, D.K., Sumarmi, S. Citra Tubuh Pada Remaja Perempuan Gemuk Dan Tidak Gemuk: Studi Cross Sectional. Amerta Nutr. 1, 398-405 (2017). 